\title{
THE EFFECT OF HAND HYGIENE INTERVENTION ON THE KNOWLEDGE AND SKILLS LEVEL OF SCHOOL CHILDREN
}

\author{
Nurlela Mufida ${ }^{1}$, Moses Glorino Rumambo Pandin ${ }^{2}$ \\ Doctor of Nursing Study Program, Faculty of Nursing Universitas Airlangga ${ }^{1}$ \\ Professor of the Faculty of Humanities, Airlangga University ${ }^{2}$ \\ Email : \\ nurlela.mufida-2021@fkp.unair.ac.id ${ }^{1}$, moses.glorino (at) fib.unair.ac.id ${ }^{2}$
}

\begin{abstract}
Background: Hand washing is an alternative, effective and inexpensive method that can be used to prevent infectious diseases. Washing hands with soap can improve children's health. The purpose of this study was to determine the effect of hand hygiene intervention on the level of knowledge and skills of elementary school students. The method used to conduct this research is a critical review, namely by reviewing articles from databases such as Google Scholar, Pubmed, Direct, Medline. The search keywords used were: quantitative studies on delivery, intervention, hand hygiene, skills, children, and primary school. The selected articles are articles that meet the standard writing criteria, which were published between 2017-2021, both in English and Indonesian. Based on these evaluation criteria, 20 (twenty) studies were obtained. From the results of a literature search, several studies on the use of intervention strategies to provide hand hygiene health education found that although there were other intervention strategies to improve hand hygiene, there were significant differences in both knowledge and skills after being given the intervention.
\end{abstract}

Keywords: hand hygiene intervention, knowledge, skills

\section{INTRODUCTION}

School-age is an important period for the formation of clean and healthy living habits in children, who in the future are expected to become agents of change who can encourage healthy living in schools, communities, and the home environment (Nuraida, 2015). One of the strategic places in promoting health is Educational Institutions. Habits carried out by a child at school will also be carried out at home which is expected to influence the behavior of other family members (Solehati, 2015).

Hand hygiene is cleaning dirt by washing with water which can inhibit or kill bacteria acquired on the skin of the hands due to human contact with the environment, thereby preventing infections transmitted by hands. Failure to perform 
proper hand hygiene is a major cause of infection and the spread of resistant microorganisms (Hidayah \& Ramadhani, 2019).

The habit of washing hands to maintain cleanliness is often forgotten and not noticed by many people, even though this habit has a positive influence that can affect the improvement of the health status of themselves and those around them.

The results of the literature reveal that school children have not realized that clean living behaviors such as the habit of washing hands in daily life, both in the school environment and in the playground, can improve their health. Children often eat food using unwashed hands. This habit is one of the factors that contribute to the incidence of diarrheal diseases and other infectious diseases. Based on the above phenomenon, the authors are interested in conducting a literature search as a first step to determine the effect of providing hand hygiene interventions on the level of knowledge and skills of school children.

\section{METHOD}

The articles analyzed were obtained from search results across databases such as Google Scholar, Science Direct, Medline, and Pubmed using the keywords: delivery, education, health, hand hygiene, skills, students, elementary school. Articles reviewed are articles that have met the criteria based on the PICO, with a publication range from 2017-2021, which are written in Indonesian and English. The inclusion criteria must include the most effective and applicable methods in terms of time and tools to improve hand hygiene skills in elementary school students. The articles are then evaluated using a critical appraisal and in the form of a PRISMA guide. From the literature review, there are 20 (twenty) articles. The PRISMA flowchart used to determine the literature can be seen as follows: 


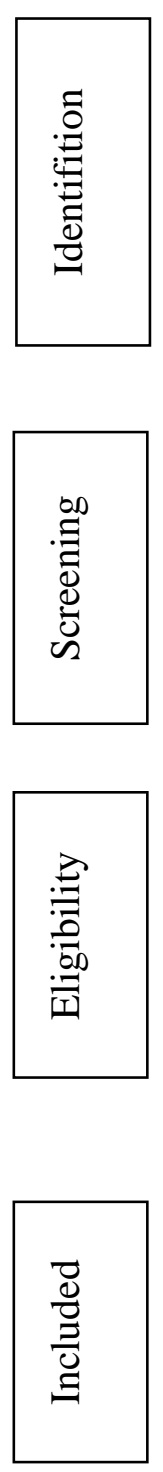

Figure 1. PRISMA Flowchart
Articles retrieved via database: Science

Direct ( $n=287)$, PubMed ( $n=169)$,

ProQuest $(\mathrm{n}=412)$

(N=895 per 13 September 2021)

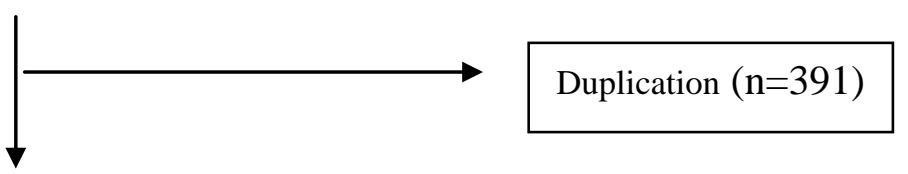

Screening $(n=504)$

Full-text articles that can be accessed $(n=102)$

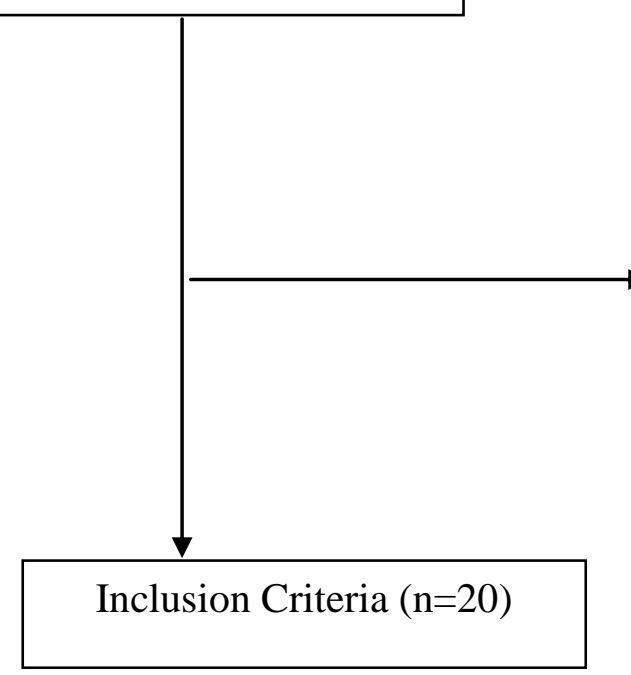

Issued, with reason:

1-hour initiation $(\mathrm{n}=12)$

Paper Policy $(\mathrm{n}=8)$

Non-English $(\mathrm{n}=19)$ $(\mathrm{n}=7)$ Duplication of publications $(\mathrm{n}=5)$ Lack of focus on the keywords being searched for $(n=26)$
Article not found
Less relevant $(n=402)$ 


\section{RESULT}

Table 1. Summary of review results

\begin{tabular}{|c|c|c|c|c|}
\hline No & $\begin{array}{l}\text { Authors and } \\
\text { Titles }\end{array}$ & Purposes & $\begin{array}{l}\text { Method (Design. } \\
\text { Variables, Samples, } \\
\text { and Instruments) }\end{array}$ & Result \\
\hline 1. & $\begin{array}{l}\text { Ni Ketut Vera } \\
\text { Parasyanti, et al; } \\
2020 \\
\text { Health } \\
\text { Education } \\
\text { Handwashing } \\
\text { with Soap using } \\
\text { Video on the } \\
\text { ability to wash } \\
\text { hands in } \\
\text { elementary } \\
\text { school students }\end{array}$ & $\begin{array}{l}\text { analyzed the } \\
\text { effect of health } \\
\text { education on } \\
\text { hand washing } \\
\text { using soap } \\
\text { (CTPS) with } \\
\text { video media on } \\
\text { the ability to } \\
\text { wash hands in } \\
\text { third grade } \\
\text { students }\end{array}$ & $\begin{array}{l}\text { D: pre-experiment } \\
\text { approach using one } \\
\text { group pretest } \\
\text { posttest design } \\
\text { S: } 27 \text { respondents } \\
\text { V: the ability to } \\
\text { wash hands before } \\
\text { and after watching } \\
\text { the video. } \\
\text { I: checklist sheet and } \\
\text { handwashing } \\
\text { observation sheet } \\
\text { that has been } \\
\text { determined. } \\
\text { A: Wilcoxon Signed } \\
\text { Rank Test (P value = } \\
0,05 \text { ). }\end{array}$ & $\begin{array}{l}\text { After receiving health } \\
\text { education about } \\
\text { handwashing with soap } \\
\text { using a video about the } \\
\text { ability to wash hands, } \\
\text { there was a significant } \\
\text { change in the } \\
\text { handwashing behavior } \\
\text { of students in class III } \\
\text { SDN } 1 \text { Berangbang } \\
\text { Jembrana. }\end{array}$ \\
\hline 2. & $\begin{array}{l}\text { Arbianingsih, et } \\
\text { al; } 2018 \\
\text { Arbi Care } \\
\text { Application } \\
\text { Increases } \\
\text { Preschool } \\
\text { Children's } \\
\text { Hand-Washing } \\
\text { Self-Efficacy } \\
\text { among } \\
\text { Preschool } \\
\text { Children }\end{array}$ & $\begin{array}{l}\text { to test and } \\
\text { determine the } \\
\text { effectiveness of } \\
\text { an Android } \\
\text { mobile game } \\
\text { application, } \\
\text { namely ARBI } \\
\text { CARE among } \\
\text { preschool } \\
\text { children as a } \\
\text { means to } \\
\text { prevent diarrhea } \\
\text { and build self- } \\
\text { efficacy in } \\
\text { washing hands }\end{array}$ & $\begin{array}{l}\text { D: Approach: a pre- } \\
\text { and post-test control } \\
\text { group and time } \\
\text { series design } \\
\text { S: } 60 \text { respondents } \\
\text { V: self-efficacy, } \\
\text { hand washing skills } \\
\text { I: Observation and } \\
\text { questionnaire } \\
\text { A: GLMRM test }\end{array}$ & $\begin{array}{l}\text { Android-based } \\
\text { educational games can } \\
\text { be an effective medium } \\
\text { to } \\
\text { handwashing } r \text { increase } \\
\text { efficacy in preschool } \\
\text { children, } \\
\text { helping thereby } \\
\text { diarrhea. }\end{array}$ \\
\hline 3. & $\begin{array}{l}\text { Lorna Kwai, et } \\
\text { al; } 2020 \\
\text { Effectiveness of } \\
\text { "Hand Hygiene }\end{array}$ & $\begin{array}{l}\text { to determine the } \\
\text { effectiveness of } \\
\text { a 4-week series } \\
\text { of educational } \\
\text { sessions, }\end{array}$ & $\begin{array}{l}\text { D: quasi- } \\
\text { experimental } \\
\text { S: children aged 5-6 } \\
\text { years in kindergarten } \\
\text { (TK) }\end{array}$ & $\begin{array}{l}\text { The results of this study } \\
\text { have implications for } \\
\text { school health educators } \\
\text { and parents to promote } \\
\text { hand hygiene (HH) }\end{array}$ \\
\hline
\end{tabular}




\begin{tabular}{|c|c|c|c|c|}
\hline & $\begin{array}{l}\text { Fun Month" for } \\
\text { Kindergarten } \\
\text { Children: A } \\
\text { Pilot Quasi- } \\
\text { Experimental } \\
\text { Study }\end{array}$ & $\begin{array}{l}\text { covering the } \\
\text { cognitive } \\
\text { developmental } \\
\text { stages of } \\
\text { children, in } \\
\text { increasing their } \\
\text { knowledge and } \\
\text { promoting hand } \\
\text { hygiene } \\
\text { practices. }\end{array}$ & $\begin{array}{l}\text { V: Knowledge Level } \\
\text { of Hand Hygiene } \\
\text { Behavior } \\
\text { I: questionnaire and } \\
\text { elements of the Hand } \\
\text { Hygiene Education } \\
\text { Program } \\
\text { A: Whitney U-test }\end{array}$ & $\begin{array}{l}\text { practices among } \\
\text { children at home and at } \\
\text { the school level. }\end{array}$ \\
\hline 4. & $\begin{array}{l}\text { Ernestina A-M., } \\
\text { et al; } 2020 . \\
\text { Effectiveness of } \\
\text { a hand hygiene } \\
\text { program to } \\
\text { reduce acute } \\
\text { gastroenteritis at } \\
\text { child care } \\
\text { centers: A } \\
\text { cluster- } \\
\text { randomized trial }\end{array}$ & $\begin{array}{l}\text { to assess the } \\
\text { effectiveness of } \\
\text { education and } \\
\text { hand hygiene } \\
\text { programs in } \\
\text { child care } \\
\text { centers (DCC) } \\
\text { and homes on } \\
\text { the incidence of } \\
\text { acute } \\
\text { gastroenteritis } \\
\text { (AGE) in } \\
\text { children attending DCC. } \\
\text { atten }\end{array}$ & $\begin{array}{l}\text { D: A randomized, } \\
\text { controlled, open } \\
\text { study } \\
\text { S: } 911 \text { respondents } \\
\text { V: Risk factors for } \\
\text { acute gastroenteritis } \\
\text { included in the } \\
\text { stratified model } \\
\text { I: handwashing } \\
\text { intervention. } \\
\text { A: A multilevel } \\
\text { Poisson regression } \\
\text { model }\end{array}$ & $\begin{array}{l}\text { showed that a hand } \\
\text { hygiene program that } \\
\text { included hand sanitizer } \\
\text { was most effective in } \\
\text { the winter months with } \\
\text { the highest incidence of } \\
\text { AGE in children in } \\
\text { DCCs. Furthermore, the } \\
\text { greatest reductions in } \\
\text { AGE episodes occurred } \\
\text { in children who } \\
\text { participated in a hand } \\
\text { hygiene program } \\
\text { including hand sanitizer } \\
\text { and action education for } \\
\text { DCC staff, parents, and } \\
\text { children and were } \\
\text { vaccinated } \\
\text { rotavirus. }\end{array}$ \\
\hline 5 & $\begin{array}{l}\text { Cheerful } \\
\text { Hadem, et al; } \\
2018 \\
\text { Effectiveness of } \\
\text { Child To Child } \\
\text { Approach on } \\
\text { Knowledge and } \\
\text { Practice } \\
\text { Regarding } \\
\text { Importance of } \\
\text { Hand Washing } \\
\text { Among Primary } \\
\text { School Children }\end{array}$ & $\begin{array}{l}\text { To evaluate the } \\
\text { effectiveness of } \\
\text { the child-to- } \\
\text { child approach } \\
\text { by comparing } \\
\text { the pre and post- } \\
\text { test values of } \\
\text { knowledge and } \\
\text { practice }\end{array}$ & $\begin{array}{l}\text { D: Quasi- } \\
\text { Experimental one } \\
\text { group Pre-test Post- } \\
\text { test } \\
\text { S: } 60 \text { respondents } \\
\text { V: knowledge, hand } \\
\text { washing skills, child } \\
\text { to child intervention } \\
\text { I: Questionnaire } \\
\text { A: test t-test }\end{array}$ & $\begin{array}{l}\text { The child-to-child } \\
\text { approach is an effective } \\
\text { method for teaching } \\
\text { health concepts such as } \\
\text { hand washing among } \\
\text { school children }\end{array}$ \\
\hline
\end{tabular}




\begin{tabular}{|c|c|c|c|c|}
\hline 6. & $\begin{array}{l}\text { Samantha L. } \\
\text { Lange, et al; } \\
2019 \\
\text { Effect of a } \\
\text { simple } \\
\text { intervention on } \\
\text { hand hygiene- } \\
\text { related diseases } \\
\text { in preschools in } \\
\text { South Africa: } \\
\text { research } \\
\text { protocol for an } \\
\text { intervention } \\
\text { study }\end{array}$ & $\begin{array}{l}\text { The study aimed } \\
\text { to determine } \\
\text { whether HH } \\
\text { interventions } \\
\text { could reduce } \\
\text { HH-related } \\
\text { illnesses among } \\
\text { 4-5-year-old } \\
\text { preschool } \\
\text { children and to } \\
\text { improve HH } \\
\text { practices in } \\
\text { these children. }\end{array}$ & $\begin{array}{l}\text { D: random } \\
\text { distribution } \\
\text { control of } \\
\text { experimental } \\
\mathrm{S}: 70 \text { children aged } \\
4-5 \text { years } \\
\mathrm{V} \text { : interactive } \\
\text { learning, parental } \\
\text { information, } \\
\text { improvement of } \mathrm{HH} \\
\text { facilities } \\
\text { I: questionnaire and } \\
\text { video } \\
\text { A: Poisson } \\
\text { regression }\end{array}$ & $\begin{array}{l}\text { HH behavior is self- } \\
\text { reported and this may } \\
\text { result in response bias, } \\
\text { however, these results } \\
\text { will be cross-checked } \\
\text { with HH observations } \\
\text { and swab hands }\end{array}$ \\
\hline 7. & $\begin{array}{l}\text { Daniel Eshetu, } \\
\text { Tigist Kifle, et } \\
\text { al;2020 } \\
\text { Knowledge, } \\
\text { Attitudes, and } \\
\text { Practices of } \\
\text { Hand } \\
\text { Washing among } \\
\text { Aderash } \\
\text { Primary } \\
\text { Schoolchildren } \\
\text { in Yirgalem } \\
\text { Town, Southern } \\
\text { Ethiopia }\end{array}$ & $\begin{array}{l}\text { To be able to } \\
\text { find out about } \\
\text { the knowledge, } \\
\text { attitudes, and } \\
\text { practices of } \\
\text { handwashing in } \\
\text { schoolchildren } \\
\text { at SD Aderash } \\
\text { in the city of } \\
\text { Yirgalem. }\end{array}$ & $\begin{array}{l}\text { D: A cross-sectional } \\
\text { study } \\
\text { S: } 279 \text { respondents } \\
\text { V: Knowledge, } \\
\text { attitude, hand } \\
\text { washing practice } \\
\text { I: questionnaire } \\
\text { A: Epi-Info version } \\
7 \text { and exported to } \\
\text { SPSS version } 20\end{array}$ & $\begin{array}{l}\text { There are }>60 \% \text { of } \\
\text { school children have } \\
\text { good knowledge and } \\
\text { show a positive attitude } \\
\text { towards hand washing, } \\
\text { the correct } \\
\text { handwashing practice is } \\
<40 \%\end{array}$ \\
\hline 8 & $\begin{array}{l}\text { Julie Watson, et } \\
\text { al; } 2018 \\
\text { Child's play: } \\
\text { Harnessing play } \\
\text { and curiosity } \\
\text { motives to } \\
\text { improve child } \\
\text { handwashing } \\
\text { in a } \\
\text { humanitarian } \\
\text { setting }\end{array}$ & $\begin{array}{l}\text { to determine the } \\
\text { long-term } \\
\text { behavioral and } \\
\text { health impacts } \\
\text { of such } \\
\text { interventions } \\
\text { when } \\
\text { administered on } \\
\text { a larger scale in } \\
\text { a humanitarian } \\
\text { context }\end{array}$ & $\begin{array}{l}\text { D: controlled study } \\
\text { design before and } \\
\text { after (CBA) } \\
\text { S: } 80 \text { respondents } \\
\text { V: child } \\
\text { characteristics, } \\
\text { handwashing } \\
\text { intervention, } \\
\text { handwashing with } \\
\text { soap. } \\
\text { I: questionnaire, } \\
\text { cheat toy. } \\
\text { A: difference-in- }\end{array}$ & $\begin{array}{l}\text { Our results provide } \\
\text { evidence that these } \\
\text { ready-to-implement } \\
\text { interventions can be } \\
\text { effective in improving } \\
\text { child handwashing } \\
\text { practices in } \\
\text { humanitarian settings } \\
\text { while facilitating rapid } \\
\text { implementation in the } \\
\text { context of humanitarian } \\
\text { emergencies. }\end{array}$ \\
\hline
\end{tabular}




\begin{tabular}{|c|c|c|c|c|}
\hline & & & $\begin{array}{l}\text { difference analysis } \\
\text { via multilevel } \\
\text { mixed-effects } \\
\text { Poisson model. }\end{array}$ & \\
\hline 9 & $\begin{array}{l}\text { Smitha M. M, et } \\
\text { al; } 2018 \\
\text { Effectiveness of } \\
\text { Child-to-Child } \\
\text { Approach on } \\
\text { Practice of Hand } \\
\text { Washing } \\
\text { Among School } \\
\text { Children in a } \\
\text { Selected School } \\
\text { at } \\
\text { Mangalore }\end{array}$ & $\begin{array}{l}\text { The } \\
\text { effectiveness of } \\
\text { the child-to- } \\
\text { child approach } \\
\text { in handwashing } \\
\text { practice. }\end{array}$ & $\begin{array}{l}\text { D: Quantitative } \\
\text { evaluative research } \\
\text { approach \& pre- } \\
\text { experiment with One } \\
\text { group pre-test and } \\
\text { post-test design } \\
\text { S: } 75 \text { respondents } \\
\text { V: knowledge, hand } \\
\text { washing skills } \\
\text { I: questionnaire } \\
\text { A: and independent- } \\
\text { t-test, chi-square, } \\
\text { and fisher's exact test }\end{array}$ & $\begin{array}{l}\text { Peer group training, } \\
\text { child to child approach, } \\
\text { and proper motivation } \\
\text { are effective methods to } \\
\text { teach children healthy } \\
\text { habits such as hand } \\
\text { washing and other } \\
\text { common issues } \\
\text { concerning children. }\end{array}$ \\
\hline 10 & $\begin{array}{l}\text { Sri Wahyuni, et } \\
\text { al; } 2017 \\
\text { Improving } \\
\text { handwashing } \\
\text { behavior with } \\
\text { modeling } \\
\text { techniques in the } \\
\text { school-age } \\
\text { group }\end{array}$ & $\begin{array}{l}\text { to improve } \\
\text { handwashing } \\
\text { behavior with } \\
\text { modeling } \\
\text { techniques in } \\
\text { elementary } \\
\text { school-age } \\
\text { children (6-12 } \\
\text { years). }\end{array}$ & $\begin{array}{l}\text { D: } \\
\text { experimental with } \\
\text { the non-equivalent } \\
\text { group and before- } \\
\text { after design } \\
\mathrm{S}: 38 \text { intervention } \\
\text { group and } 38 \text { control } \\
\text { group } \\
\text { V: } \\
\text { characteristics family } \\
\text { school children, the } \\
\text { ability to wash hands } \\
\text { before and after the } \\
\text { modeling technique } \\
\text { intervention } \\
\text { I: questionnaire, } \\
\text { modeling technique } \\
\text { intervention } \\
\text { A: independent t-test }\end{array}$ & $\begin{array}{l}\text { The results showed that } \\
\text { handwashing practice } \\
\text { increased } \\
\text { modeling with } \\
\text { (p=0.000). Betivity } \\
\text { modification } \\
\text { modeling techniques } \\
\text { can be applied as an } \\
\text { effort to improve } \\
\text { handwashing behavior } \\
\text { in school children } \\
\text { which can be integrated } \\
\text { into school nursing } \\
\text { services }\end{array}$ \\
\hline 11 & $\begin{array}{l}\text { Afik Achsanti } \\
\text { Saputri } \\
\text {, Suryati; } 2019 \\
\text { Effect of health } \\
\text { education using } \\
\text { audiovisual on } \\
\text { knowledge of }\end{array}$ & $\begin{array}{l}\text { to increase } \\
\text { knowledge of } \\
\text { washing hands } \\
\text { with soap }\end{array}$ & $\begin{array}{l}\text { D: pre-experiment } \\
\text { with One-group pre- } \\
\text { post test design } \\
\text { S: } 44 \text { respondents } \\
\text { V: Knowledge } \\
\text { I: Questionnaire } \\
\text { A: Wilcoxon Signed } \\
\text { Ranks correlation }\end{array}$ & $\begin{array}{l}\text { there is a change after } \\
\text { being given health } \\
\text { education using audio- } \\
\text { visual on CTPS } \\
\text { knowledge in grade IV } \\
\text { children }\end{array}$ \\
\hline
\end{tabular}




\begin{tabular}{|c|c|c|c|c|}
\hline & $\begin{array}{l}\text { handwashing } \\
\text { with soap } \\
\text { (CTPS) in } \\
\text { fourth-grade } \\
\text { children at MI } \\
\text { Jamilurrahman } \\
\text { Bantul }\end{array}$ & & test & \\
\hline 12 & 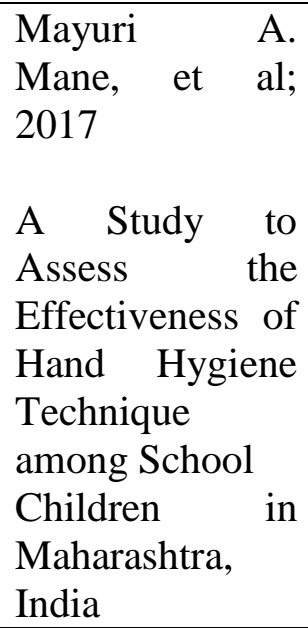 & $\begin{array}{l}\text { to assess the } \\
\text { effectiveness of } \\
\text { hand hygiene } \\
\text { techniques } \\
\text { demonstration } \\
\text { of hand hygiene } \\
\text { practices in } \\
\text { elementary school children. }\end{array}$ & $\begin{array}{l}\text { D: one group pre- } \\
\text { test, post-test design } \\
\text { S: } 60 \text { respondents } \\
\text { V: knowledge, hand } \\
\text { washing skills } \\
\text { I: SOP for washing } \\
\text { hands } \\
\text { A: Descriptive and } \\
\text { inferential statistics } \\
\text { by considering the } \\
\text { objectives }\end{array}$ & $\begin{array}{l}\text { demonstration of hand } \\
\text { hygiene techniques on } \\
\text { hand hygiene is } \\
\text { considered effective in } \\
\text { improving hand } \\
\text { hygiene practices in } \\
\text { elementary school } \\
\text { children so that the } \\
\text { hand hygiene technique } \\
\text { steps are easy to } \\
\text { understand. }\end{array}$ \\
\hline 13 & $\begin{array}{l}\text { Octa, A; } 2019 \\
\text { The relationship } \\
\text { between } \\
\text { knowledge and } \\
\text { attitudes } \\
\text { towards } \\
\text { handwashing } \\
\text { behavior in the } \\
\text { Pegirian village } \\
\text { community }\end{array}$ & $\begin{array}{l}\text { Identifying the } \\
\text { relationship } \\
\text { between } \\
\text { knowledge and } \\
\text { attitudes towards } \\
\text { hand washing in } \\
\text { RW III Pegirian } \\
\text { Village }\end{array}$ & $\begin{array}{l}\text { D: quantitative with } \\
\text { cross-sectional } \\
\text { design } \\
\text { S: } 84 \text { respondents } \\
\text { V: knowledge, } \\
\text { attitude } \\
\text { I: Questionnaire } \\
\text { A: Spearman } \\
\text { correlation test }\end{array}$ & $\begin{array}{l}\text { The existence and } \\
\text { strength of the } \\
\text { relationship between } \\
\text { knowledge and attitudes } \\
\text { towards hand washing } \\
\text { is positive }\end{array}$ \\
\hline 14 & $\begin{array}{l}\text { Agus Erwin } \\
\text { Ashari, et al; } \\
2020 \\
\text { Improving } \\
\text { Knowledge, } \\
\text { Attitudes, and } \\
\text { Practices of } \\
\text { Handwashing } \\
\text { with Soap in } \\
\text { Class } \\
\text { Elementary } \\
\text { School Children }\end{array}$ & $\begin{array}{l}\text { knowing and } \\
\text { analyzing the } \\
\text { relationship } \\
\text { between } \\
\text { Handwashing } \\
\text { with Soap } \\
(\mathrm{CTPS}) \quad \text { and } \\
\text { increasing } \\
\text { knowledge, } \\
\text { attitudes, and } \\
\text { practices of } \\
\text { hand hygiene } \\
\text { using soap at the }\end{array}$ & $\begin{array}{l}\text { D: non-equivalent } \\
\text { pre-post test control } \\
\text { group design } \\
\text { S: } 61 \text { respondents } \\
\text { V: knowledge, } \\
\text { attitude, hand } \\
\text { washing practice } \\
\text { I: Questionnaire } \\
\text { A: Wilcoxon test }\end{array}$ & $\begin{array}{l}\text { The results showed that } \\
\text { there were no } \\
\text { significant differences } \\
\text { in knowledge, attitudes, } \\
\text { and practices before } \\
\text { and after the test in the } \\
\text { control group, and no } \\
\text { significant differences } \\
\text { in knowledge, attitudes, } \\
\text { and practices before } \\
\text { and after CTPS training } \\
\text { in the intervention } \\
\text { group. There was a }\end{array}$ \\
\hline
\end{tabular}




\begin{tabular}{|c|c|c|c|c|}
\hline & $\begin{array}{l}\text { through } \\
\text { Handwashing } \\
\text { with Soap } \\
\text { Exercise. }\end{array}$ & $\begin{array}{l}\text { age } \\
\text { elementary } \\
\text { school children } \\
\text { in } \quad \text { Mamuju } \\
\text { District }\end{array}$ & & $\begin{array}{l}\text { difference in knowledge } \\
\text { between the } \\
\text { intervention group and } \\
\text { the control group, but } \\
\text { no difference in attitude } \\
\text { or practice. }\end{array}$ \\
\hline 15 & $\begin{array}{l}\text { Padila, et al; } \\
2020 \\
\text { Learning to } \\
\text { wash hands in } \\
\text { seven steps } \\
\text { through the } \\
\text { demonstration } \\
\text { method for early } \\
\text { childhood }\end{array}$ & $\begin{array}{l}\text { To evaluate the } \\
\text { effectiveness of } \\
\text { the } \\
\text { demonstration } \\
\text { method for hand } \\
\text { washing skills at } \\
7 \text { stages of } \\
\text { preschool } \\
\text { children } \\
\text { Aisyiyah in } \\
\text { Kindergarten, } \\
\text { Bengkulu City }\end{array}$ & $\begin{array}{l}\text { D: pre-experimental } \\
\text { design with one } \\
\text { group pretest- } \\
\text { posttest } \\
\text { S: } 30 \text { respondents } \\
\text { V: The ability to } \\
\text { wash hands before } \\
\text { and after the } \\
\text { demonstration } \\
\text { I: SOP for washing } \\
\text { hands } \\
\text { A: Wilcoxson test }\end{array}$ & $\begin{array}{l}\text { Demonstration } \\
\text { intervention is very } \\
\text { effective in increasing } \\
\text { the ability to wash } \\
\text { hands by } 7 \text { steps in } \\
\text { early childhood. }\end{array}$ \\
\hline 16 & $\begin{array}{l}\text { Yulianto, et al; } \\
2018 \\
\text { The } \\
\text { effectiveness of } \\
\text { media ( video, } \\
\text { image, and } \\
\text { song) to } \\
\text { Handwashing } \\
\text { behavior in } 1^{\text {ST }}- \\
3^{\text {RD }} \\
\text { graders of SDIT } \\
\text { permata } \\
\text { Mulia } \\
\text { Mojokerto }\end{array}$ & $\begin{array}{l}\text { to find out the } \\
\text { effectiveness of } \\
\text { the video, } \\
\text { image, and song } \\
\text { method on } \\
\text { handwashing } \\
\text { behavior }\end{array}$ & $\begin{array}{l}\text { D: Pre-experiment } \\
\text { design with pre-post } \\
\text { test design } \\
\mathrm{S}: 90 \text { respondents } \\
\mathrm{V} \text { : handwashing } \\
\text { behavior, hand } \\
\text { washing } \\
\text { intervention } \\
\mathrm{I}: \text { videos, pictures, } \\
\text { songs. } \\
\text { A: compare mean } \\
\text { scores }\end{array}$ & $\begin{array}{l}\text { The song method is } \\
\text { more effective than the } \\
\text { simulation method in } \\
\text { improving the ability to } \\
\text { wash hands }\end{array}$ \\
\hline 17 & $\begin{array}{l}\text { Tri Nugroho, et } \\
\text { al; } 2020 \\
\text { The Effect of } \\
\text { Health } \\
\text { Education Using } \\
\text { Audio-Visual } \\
\text { Media on } \\
\text { Knowledge of } \\
\text { Hand Washing }\end{array}$ & $\begin{array}{l}\text { to be able to } \\
\text { determine the } \\
\text { effect of health } \\
\text { education with } \\
\text { audiovisual } \\
\text { media on } \\
\text { knowledge of } \\
\text { handwashing } \\
\text { with soap in } \\
\text { grade } 2\end{array}$ & $\begin{array}{l}\text { D: pre-experiment } \\
\text { with one group } \\
\text { pretest-posttest } \\
\text { approach } \\
\mathrm{S}: 46 \text { respondents } \\
\mathrm{V} \text { : Knowledge } \\
\text { before and after } \\
\text { being given audio- } \\
\text { visual media } \\
\text { washing hands }\end{array}$ & $\begin{array}{l}\text { There has been a } \\
\text { change since the } \\
\text { introduction of health } \\
\text { education through } \\
\text { audiovisual } \\
\text { interventions given, to } \\
\text { increase knowledge } \\
\text { about handwashing } \\
\text { with soap. }\end{array}$ \\
\hline
\end{tabular}




\begin{tabular}{|c|c|c|c|c|}
\hline & $\begin{array}{l}\text { with Soap in } \\
\text { Grade } \\
\text { Elementary } \\
\text { School Children }\end{array}$ & $\begin{array}{l}\text { elementary } \\
\text { school children }\end{array}$ & $\begin{array}{l}\text { I: questionnaire } \\
\text { A: Wilcoxon Signed } \\
\text { Ranks Test }\end{array}$ & \\
\hline 18 & $\begin{array}{l}\text { Rina Mariyana, } \\
\text { et al; } 2021 \\
\text { The application } \\
\text { of the animated } \\
\text { video for } \\
\text { washing hands } \\
\text { with soap on the } \\
\text { response to } \\
\text { children at a } \\
\text { special school in } \\
\text { Bukittinggi }\end{array}$ & $\begin{array}{l}\text { To introduce an } \\
\text { animated video } \\
\text { intervention for } \\
\text { washing hands } \\
\text { with soap as a } \\
\text { response to } \\
\text { reactions to } \\
\text { children from } \\
\text { the Bukittinggi } \\
\text { Special School }\end{array}$ & $\begin{array}{l}\text { D: sequential } \\
\text { exploratory } \\
\text { S: } 34 \text { respondents } \\
\text { V: knowledge, } \\
\text { attitude, action } \\
\text { I: Questionnaire, } \\
\text { video } \\
\text { implementation } \\
\text { A: chi-square test }\end{array}$ & $\begin{array}{l}\text { Hand washing video } \\
\text { intervention must be } \\
\text { carried out on children, } \\
\text { and if the video is } \\
\text { played continuously } \\
\text { then the child's needs } \\
\text { and abilities can } \\
\text { increase the } \\
\text { effectiveness } \\
\text { washing hands }\end{array}$ \\
\hline 19 & $\begin{array}{l}\text { Yesica Devis, et } \\
\text { al; } 2018 \\
\text { Lecture } \\
\text { Methods and } \\
\text { Effective Group } \\
\text { Discussions } \\
\text { Increase } \\
\text { Students' } \\
\text { Knowledge } \\
\text { About Hand } \\
\text { Washing With } \\
\text { Soap }\end{array}$ & $\begin{array}{l}\text { Seeing the } \\
\text { effectiveness of } \\
\text { the lecture } \\
\text { method and } \\
\text { group discussion } \\
\text { in increasing the } \\
\text { knowledge of } \\
\text { fourth-grade } \\
\text { students about } \\
\text { hand soap at } \\
\text { SDN } 044 \\
\text { Pekanbaru }\end{array}$ & $\begin{array}{l}\text { D: quasi-experiment } \\
\text { using a one group } \\
\text { pre-test post-test } \\
\text { approach } \\
\text { S: } 68 \text { respondents } \\
\text { V: knowledge } \\
\text { I: questionnaire } \\
\text { A: independent T- } \\
\text { test and Mann- } \\
\text { Whitney test }\end{array}$ & $\begin{array}{l}\text { There is a difference in } \\
\text { the average knowledge } \\
\text { score after the } \\
\text { intervention using } \\
\text { either the lecture } \\
\text { method or the group } \\
\text { discussion method. } \\
\text { However, the group } \\
\text { discussion method is } \\
\text { better. }\end{array}$ \\
\hline 20 & $\begin{array}{l}\text { Balwani C.M, et } \\
\text { al; } 2019 \\
\text { Effect of a } \\
\text { school-based } \\
\text { hand hygiene } \\
\text { program for } \\
\text { Malawian } \\
\text { children: } \\
\text { A randomized } \\
\text { controlled trial }\end{array}$ & $\begin{array}{l}\text { to evaluate the } \\
\text { impact of a } \\
\text { school-based } \\
\text { hand hygiene } \\
\text { program on } \\
\text { children's } \\
\text { handwashing } \\
\text { adherence and } \\
\text { school } \\
\text { absenteeism in } \\
\text { South Africa }\end{array}$ & $\begin{array}{lr}\text { D: 2-arm } & \text { cluster } \\
\text { RCT. } & \\
\text { S: } \quad 6 \quad \text { elementary } \\
\text { schools with } 375 \\
\text { children } \\
\text { V: Hand washing } \\
\text { knowledge, } \\
\text { washing hand } \\
\text { mastery, } \\
\text { hygiene, } \\
\text { absenteeism hand } \\
\text { increase under } \quad \text { rate } \\
\text { simplified steps } \\
\text { I: questionnaire, } \\
\text { hand washing soap }\end{array}$ & $\begin{array}{l}\text { The impact of the } \\
\text { school-based hand } \\
\text { hygiene program is } \\
\text { positive. It can be used } \\
\text { in both the planning and } \\
\text { development of hand } \\
\text { hygiene protocols to } \\
\text { increase } \\
\text { schoolchildren's } \\
\text { handwashing } \\
\text { compliance rates and to } \\
\text { reduce school } \\
\text { absenteeism in } \\
\text { developing countries. }\end{array}$ \\
\hline
\end{tabular}




\begin{tabular}{|l|l|l|l|}
\hline & & $\begin{array}{l}\text { A: SPSS program } \\
\text { (software) } \\
\text { versions 23.0; IBM } \\
\text { Corp, Armonk, NY) }\end{array}$ \\
\hline
\end{tabular}

\section{DISCUSSION}

Based on the results of a systematic literature review on the effect of providing hand hygiene interventions on handwashing skills in elementary school students, namely as follows:

When searching for hand hygiene articles in this study, it was found that there were 10 studies with quasi-experimental and pre-experimental designs. This study found that there was an impact of hand hygiene interventions using different methods on the level of knowledge and skills indicated by a significant improvement in hand hygiene practices.

The selection of methods and media also determines the effectiveness of the intervention. As in the research conducted by (Ni Ketut Vera P, 2020) which showed that there was an impact of health education on handwashing with soap using video media on the ability to wash hands for class III SDN 1 Berangbang Jembrana. This is also in line with research by (Afik Achsanti Saputri, Suryati; 2019) on the effect of audiovisual health education on CTPS knowledge for Class IV MI Jamilurrahman Bantul children. In addition, different simulation interventions were carried out by (Yulianto, et al; 2018) with the song method which was more effective than the simulation method in improving the ability to wash hands. Meanwhile, in the study (Agus Erwin Ashari, et al; 2020) the results showed that there were no significant differences in knowledge, attitudes, and practices between the pre-test and post-test in the control group. In the intervention group, there was no significant difference in knowledge, attitude, or practice before and after CTPS exercise. There is a difference in knowledge between the intervention group and the control group, but there is no difference in attitude and practice

When deciding on methods and media, the effectiveness of the intervention is also needed. Several studies, such as research by Arbianingsih (2018), show that the use of intervention strategies in the form of games (android-based educational games) 
can be an effective medium to increase handwashing self-efficacy in preschool children, thereby helping prevent diarrhea. Even in research (Rina Mariyana, et al; 2021) to activate children's ability to wash their hands, it can be taught through animated videos that are played repeatedly.

Based on the evaluation of the literature that has been obtained, it is known that there is an effect of various hand hygiene interventions on the knowledge and skills of elementary school students through the lecture and role-playing methods combined with audiovisual media. This is because, according to the survey above, the average skill level reaches scores were quite high, and in most studies, the health education intervention improved after washing hands with audiovisual media such as lectures, demonstrations, and role-playing. The increase was also higher in the intervention group than in the control group.

\section{CONCLUSION}

In the collection of literature contained in this study, it can be concluded that there is a significant increase in handwashing behavior in students who are intervened with health education methods. demonstrations and audiovisuals. In addition, the selection of attractive media also affects the effectiveness of an intervention. Although some of the literature studies obtained have intervention strategies to improve other hand hygiene skills, lecture and role-playing methods and the use of audiovisual intervention strategies have been shown to make a significant difference after the intervention increased.

\section{REFERENCES}

1. Afik Achsanti Saputri, Suryati. (2019). Pengaruh pendidikan kesehatan menggunakan audiovisual Terhadap Pengetahuan Cuci Tangan Pakai Sabun (CTPS) Pada Anak Kelas IV Di MI Jamilurrahman Bantul; Jurnal Medika Respati Vol. 14 (3) Juli 2019. DOI: https://doi.org/10.35842/mr.v14i3.231

2. Agus Erwin Ashari, dkk. (2020). Peningkatan Pengetahuan, Sikap Dan Praktik Cuci Tangan Pakai Sabun Pada Anak Kelas V Sekolah Dasar Melalui Senam Cuci Tangan Pakai Sabun ; Jurnal Ilmiah Permas: Jurnal Ilmiah STIKES Kendal

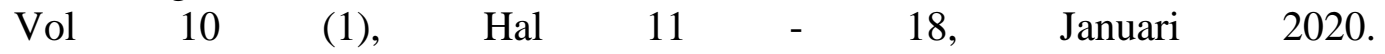
DOI: https://doi.org/10.32583/pskm.v10i1.635 
3. Arbianingsih, et al. (2018)Arbi Care Application Increases Preschool Children's Hand-Washing Self-Efficacy among Preschool Children; Enferm Clin. 2018;28(Suppl 1 Part A):27-30. https://doi.org/10.1016/S1130-8621(18)30031-7

4. Audria Octa Anggraini Widi Lestari. (2019). Hubungan pengetahuan dan sikap terhadap perilaku cuci Tangan pada masyarakat kelurahan pegirian; Jurnal Promkes Vol. 7 ( 1 ) hal ; 23-34. doi: 10.20473/jpk.V7.I1.2019.1-11

5. Balwani Chingatichifwe Mbakaya, et al. (2019).Effect of a school-based hand hygiene program for Malawian children: A cluster randomized controlled trial; American Journal of Infection Control 00 (2019) 1-5. DOI: 10.1016/j.ajic.2019.06.009

6. Cheerful Hadem, et al . (2018). Effectiveness of Child To Child Approach on Knowledge and Practice Regarding Importance of Hand Washing Among Primary School Children; RGUHS Journal of Nursing Sciences, June 2018 / Vol8 / Issue-1.

7. Daniel Eshetu, Tigist Kifle, et al . (2020). Knowledge, Attitudes, and Practices of HandWashing among Aderash Primary Schoolchildren in Yirgalem Town, Southern Ethiopia; Journal of Multidisciplinary Healthcare 2020:13 759-768. DOI: $10.2147 / J M D H . S 257034$

8. Ernestina A.M, et al. (2020). Effectiveness of a hand hygiene program to reduce acute gastroenteritis at child care centers: A cluster-randomized trial; American $\begin{array}{llllll}\text { Journal of Infection Control } 000 & \text { (2020) }\end{array}$ https://doi.org/10.1016/j.ajic.2020.03.011.

9. Julie Watson, et al. (2018). Child's play: Harnessing play and curiosity motives to improve child handwashing in a humanitarian setting; International Journal of Hygiene and Environmental Health.https://doi.org/10.1016/j.ijheh.2018.09.002

10. Lorna Kwai, et al (2020). Effectiveness of "Hand Hygiene Fun Month" for Kindergarten Children: A Pilot Quasi-Experimental Study; Int. J. Environ. Res. Public Health 2020, 17, 7264; doi:10.3390/ijerph17197264

11. Mayuri A. Mane, et al . (2017) A Study to Assess the Effectiveness of Hand Hygiene Technique among School Children in Maharashtra, India; Asian Journal of Pharmaceutical Research and Health Care, Vol 9(4), 174-179, 2017. DOI: 10.18311/ajprhc/2017/15834

12. Ni Ketut Vera Parasyanti, et al (2020) Pendidikan Kesehatan Cuci Tangan Pakai Sabun dengan Video Terhadap kemampuan cuci tangan pada siswa SD; Jurnal Akademika Baiturrahim Jambi, Vol . 9 (1) hal:122-130. Doi : 10.36565/jab.v9i1.197 
13. Padila, dkk. (2020). Pembelajaran cuci tangan tujuh langkah melalui Metode demonstrasi pada anak usia dini ; Journal of Telenursing (JOTING)Volume 2, Nomor 2, Desember 2020. DOI: https://doi.org/10.31539/joting.v2i2.1395

14. Rina Mariyana, dkk . (2021). Penerapan vidio animasi cuci tangan pakai sabun Terhadap respon pada anak Di sekolah luar biasa bukittinggi ; Jurnal Endurance : Kajian Ilmiah Problema Kesehatan Vol 6(1) Februari $2021(38-45)$

15. Smitha Mariam Mathew, et al (2018). Effectiveness of Child To Child Approach on Practice of Hand Washing Among School Children in a Selected School at Mangalore; Journal of Health and Allied Sciences NU 2018; 08(01): 15-21. DOI: $10.1055 / \mathrm{s}-0040-1708739$

16. Sri wahyuni, dkk. (2017). Peningkatan perilaku mencuci tangan dengan Teknik modeling pada kelompok anak usia Sekolah; The Indonesian Journal Of Health Science, Vol. 8 (2) Juni 2017. DOI: https://doi.org/10.32528/the.v8i2.868

17. Tri Nugroho, dkk. (2020). Pengaruh Pendidikan Kesehatan Dengan Media Audio Visual Terhadap Pengetahuan Cuci Tangan Pakai Sabun Pada Anak Sd Kelas 2 ; Healthy Journal Vol. VIII No. 1, Maret 2020.

18. Yesica devis, dkk. (2017). Metode Ceramah Dan Diskusi Kelompok Efektif Meningkatkan Pengetahuan Siswa Tentang Cuci Tangan Pakai Sabun ; Jurnal Kesehatan Komunitas 2017;3(4):159-163. https://doi.org/10.25311/keskom.Vol3.Iss4.205

19. Yulianto, et al (2018). The effectiveness of media ( video, image, and song) to Handwashing behavior in $1^{\mathrm{ST}}-3^{\mathrm{RD}}$ graders of SDIT Permata Mulia Mojokerto; International Journal Of Nursing and Midwifery Science (IJNMS), Volume2, Issue 2 2, August 2018. DOI: https://doi.org/10.29082/IJNMS/2018/Vol2/Iss02/133

20. Samantha Louise Lange, et al. (2019). Effect of a simple intervention on hand hygiene-related diseases in preschools in South Africa: research protocol for an intervention study; BMJ Open 2019;9:e030656. doi:10.1136/bmjopen-2019030656 